\title{
ІНФОРМАЦІЙНІ ТЕХНОЛОГІЇ ОЦІНКИ ТЯЖКОСТІ ТА МОНІТОРИНГУ СТАНУ ДІТЕЙ 3 ЮВЕНІЛЬНИМ РЕВМАТОЇДНИМ АРТРИТОМ
}

О. П. Мінцер, Т. Ю. Дубініна

Національна медична академія післядипломної освіти імені П. Л. Шупика

\begin{abstract}
Систематизація релевантних даних кількісного моніторингу популяції дітей з рідкісними (орфанними) захворюваннями залишається складною проблемою. Для створення системи оцінки тяжкості патологічного стану та моніторингу відповіді на терапію обрана клінічна модель: діагностика та лікування дітей з ювенільним ревматоїдним артритом. Показано, що головним завданням в упорядкуванні та систематизації знань щодо орфанних захворювань $€$ визначення сукупності критеріїв оцінки тяжкості та моніторингу стану, ідентифрікації клінічної небезпеки та прогнозування виходів рідкісних захворювань. Застосування інфрормаційних технологій у вивченні орфранних захворювань може вже на перших етапах застосування допомогти в визначенні фракторів ризику, а також у створенні алгоритмів прийняття рішень щодо вибору тактики лікування хворих. Створення системи моніторингу стану та прогнозування оракторів ризику втрат здоров'я дитини потребує розробки методології створення та функціонування регістрів та розробки технологій дистанційного контролю стану хворих. Клінічна модель (спостереження за дітьми з ювенільним ревматоїдним артритом), що обрана для відпрацювання логіки моніторингу стану, виявилася валідною та пертинентною.
\end{abstract}

Ключові слова: інформаційні технології, орфанні захворювання, ювенільний ревматоїдний артрит, критерії оцінки, ризики, моніторинг.

\section{INFORMATION TECHNOLOGIES FOR EVALUATION OF SEVERITY AND MONITORING OF CHILDREN'S STATE WITH JUVENILE RHEUMATOID ARTHRITIS}

\author{
O. P. Mintser, T. Yu. Dubinina \\ Shupyk National Medical Academy of Postgraduate Education
}

Systematization of the relevant data of quantitative monitoring of the population of children with rare (orphan) diseases remains a difficult problem. When assessing the severity of the pathological condition and monitoring the response to therapy, the criteria and indices of activity of juvenile rheumatoid arthritis are introduced. Such tools are necessary for choosing therapeutic programs, forecasting the course of the disease, and assessing the risks to the patient. Determining the set of data elements for mathematical modeling tasks is the primary stage of this process.

Key words: information technology, rare diseases, juvenile rheumatoid arthritis, evaluation criteria, risks, monitoring.

\section{ИНФОРМАЦИОННЫЕ ТЕХНОЛОГИИ ОЦЕНКИ ТЯЖЕСТИ И МОНИТОРИНГА СОСТОЯНИЯ ДЕТЕЙ С ЮВЕНИЛЬНЫМ РЕВМАТОИДНЫМ АРТРИТОМ}

\author{
О. П. Минцер, Т. Ю. Дубинина \\ Национальная медицинская академия последипломного образования имени П. Л. Шупика
}

Систематизация релевантных данных количественного мониторинга популяции детей с редкими (орфанными) заболеваниями остается сложной проблемой. Для создания системы оценки тяжести патологического состояния и мониторинга ответа на терапию выбрана клиническая модель - диагностика и лечение детей с ювенильным ревматоидным артритом. Показано, что главной задачей в составлении и систематизации знаний по орфанным заболеваниям является определение совокупности критериев оценки тяжести и мониторинга состояния, идентификации клинической опасности и прогнозирования исходов редких заболеваний. Применение информационных технологий в изучении орфанных заболеваний может уже на первых этапах применения помочь в определении фракторов риска, а также в создании алгоритмов принятия решений по выбору тактики лечения больных. Создание системы мониторинга состояния и прогнозирования фракторов риска потерь здоровья требует разработки методологии создания и функционирования регистров и разработки технологий дистанционного контроля состояния больных. Клиническая модель (наблюдение за детьми с ювенильным ревматоидным артритом), выбранная для отработки логики мониторинга состояния, оказалась валидной и пертинентной.

Ключевые слова: инорормационные технологии, орфанные заболевания, ювенильный ревматоидный артрит, критерии оценки, риски, мониторинг.

(C) О. П. Мінцер, Т. Ю. Дубініна 
Вступ. Рідкісні захворювання виявляються у 6-8 \%, або в 30 млн людей з 508 млн населення країн Європейського Союзу. Це приблизно дорівнює оцінній поширеності цукрового діабету в європейському регіоні, яка у 2013 році становила 6,8 \% з 658,7 млн дорослих у віці 20-79 років. Така ситуація ілюструє парадокс раритету: кожне захворювання зустрічається рідко, але колективно рідкісні захворювання зачіпають багатьох людей. Для 80 \% пацієнтів захворювання має очевидний вплив на тривалість життя, а у 35 \% хвороба або її ускладнення призводять до смерті. Понад 65 \% випадків рідкісних захворювань викликають інвалідність, яка впливає на повсякденне життя, у 9 \% випадків автономія повністю втрачена. Глобальною проблемою громадського здоров’ я ці захворювання є через багаторазову госпіталізацію пацієнтів протягом усього життя та їх тривалу діагностичну одіссею. За баченням ВООЗ сьогодні існує більше можливостей впливу на ситуацію завдяки сучасним знанням про геном людини [7].

Постановка проблеми. Складний епідеміологічний профіль рідкісних захворювань тільки підкреслює корисність системи моніторингу з метою вирішення глобальних задач. Зарубіжний досвід підтверджує наукову, організаційну та фінансову підтримку нових регістрів і колекцій даних для ефективного планування допомоги пацієнтам 3 рідкісними захворюваннями, покращення стандартизації терапії та порівняння результатів діяльності [9, 10].

В Україні проблема захисту громадян, які страждають на рідкісні (орфанні) захворювання, набула загальнодержавного значення у 2014 році, відповідно до внесених зміни у Закон України «Основи законодавства України про охорону здоров’я». На сьогодні формується система допомоги цим пацієнтам, створюються медичні центри, здійснюються наукові дослідження.

Загальноприйнятим є те, що для того, щоб займатися веденням пацієнтів з орфаними метаболічними захворюваннями, необхідно одночасно володіти знаннями в сфері педіатрії, неврології, медичної генетики, біохімії і молекулярної біології. Таким чином, справа ведення орфанних захворювань це сфера відповідальності мультидисциплінарної команди, а в рамках сучасних уявлень - трансдисціплінарних висококваліфікованих фахівців, які сумісно приймають рішення по всьому спектру питань діагностики та лікування. Цей метод використовується в багатьох країнах, зокрема в Україні (центр «Охматдит») та в Польщі (де функціонує кілька подібних центрів і була впроваджена програма розширеного неонатального скринінгу орфанних метаболічних захворювань).

Доступ до інформації про рідкісні захворювання та створення центрів експертизи є ключовим елементом рекомендацій Ради Європи та основою для національних планів і стратегій у сфері рідкісних захворювань. Мережа таких центрів у Європейському Союзі сьогодні забезпечує відповідну своєчасну діагностику і високу якість лікування пацієнтів, отримання деталізованих клінічних даних та надає доступ до сучасних знань про рідкісні хвороби [9]. Визначення набору елементів для експертних систем $є$ актуальною темою наукових досліджень у Європі та США. Застосування релевантних даних, які загальновизнані для контексту як клінічних досліджень, так і вторинного використання, в кінцевому підсумку сприятиме семантичній сумісності між системами $[6,11]$.

Беручи до уваги досить велику кількість орфанних захворювань, їхні епідеміологічні особливості (невисока зустрічальність, невиразна клініка на ранніх етапах розвитку, тощо), в теперішній час вкрай важливими стають питання ранньої їх діагностики та набувають критичності маніфестаційні ознаки погіршення стану (ідентифікація небезпеки).

Рання і точна діагностика рідкісного захворювання має вирішальне значення. Нинішня ситуація з ідентифікацією конкретної рідкісної хвороби не оптимістична. Статистичні дані показують, що час від появи клінічних симптомів до встановлення правильного діагнозу становить 5-30 років у середньому [1]. Це значною мірою обумовлено відсутністю у лікарів наукових знань стосовно рідкісних хвороб. Більше того, рідкісні захворювання іноді замасковуються безліччю інших умов, що може призвести до встановлення неправильного діагнозу або високоризикових затримок точного діагностування. Отже, неправильний або пізній діагноз може призвести до численних медичних консультацій, неточностей лікування, неадекватної поведінки та недостатньої підтримки членів сім’ї хворого та навіть народження з тією ж самою хворобою інших дітей в одній сім’ї.

Підкреслимо, що будівництво мереж діагностики та лікування, підготовка лікарів у відповідних сферах та відповідна перевірка рідкісних захворювань у великій популяції, особливо у дітей, допоможе лише в певній мірі ранньому та 
всебічному виявленню пацієнтів 3 рідкісними захворюваннями.

Необхідні принципово нові підходи до виявлення та корекції станів хворих. Зокрема слід виявити спеціальні маркери, що можуть дозволити передбачити появу захворювання. Важливою $є$ також кількісна оцінка клінічних показників з позицій як діагностичної, так і прогностичної значимості. В теперішній час виділяють кілька груп таких клінічних проявів, які, безумовно, повинні насторожувати лікаря, тим більше якщо вони поєднуються один з одним. Насамперед, це можуть бути специфічні зміни зовнішності, клінічні ситуації, в яких дитина поволі втрачає раніше набуті нею навички, тобто демонструє очевидний регрес в психоневрологічному розвитку. Дуже часто відзначаються рецидивуючі респіраторні інфекції, зниження антропометричних показників у порівнянні з віковою нормою, затримка моторного та психомовного розвитку, кісткові деформації та ін. Вкрай важливим $€$ так зване каскадне тестування, що включає визначення ризиків у родичів, зокрема факторів генетичного стану.

Водночас, рідкість і недостатньо зрозуміла етіологія захворювання іноді може призвести до неправильних уявлень про те, що впливає на пацієнтів на різних стадіях захворювання. Таким чином, клінічна інформація про захворювання може бути оманливою.

Вкрай важливою слід вважати оцінку динаміки показників стану хворих, як з погляду на уточнення діагностики, так і вирішення прогностичних характеристик. Існуючі підходи, особливо в плані оцінки поліпшення стану хворих, слід вважати надто дискусійними [2, 8]. Проблема стосується фактів самооцінки, пов'язана з наявністю ситуацій, коли хворі на рідку хворобу не можуть адаптуватися до знецінення [3].

Мета роботи: визначення умов кількісного моніторингу стану дітей з ювенільним ревматоїдним артритом в умовах дистанційного контролю.

Результати та їх обговорення. Рекомендації Ради Європи від 8 червня 2009 року (2009/C151/02) стосовно дій в сфері рідкісних захворювань чітко визначають, що рідкісні захворювання є загрозою для здоров'я громадян Європейського Союзу, оскільки вони небезпечні для життя або хронічно виснажливі [10].

Як модель кількісного рішення проблем діагностики та моніторингу обраний ювенільний ревматоїдний артрит (хвороба Стилла). Відповідно до наказу Міністерства охорони здоров’я України від 27.10.2014 № 778 ювенільний ревматоїдний артрит (М08.0) внесено до переліку рідкісних (орфанних) захворювань.. Створення системи прийняття рішення у сфері допомоги дітям 3 ювенільним ревматоїдним артритом може значно мінімізувати існуючі ризики захворювання та адаптувати доказові стандарти для персоналізованої терапії. Важливим моментом цього процесу є вибір сукупності критеріїв, на основі яких надалі буде оцінене та прийняте рішення [1].

За офіційними статистичними даними Міністерства охорони здоров'я України поширеність ювенільного ревматоїдного артриту у 2017 році становила 0,31 на 1000 дітей віком до 18 років (абсолютні дані - 2336 дітей). Популяція дітей з ювенільним ревматоїдним артритом має різні категорії тяжкості перебігу захворювання. Окремі форми захворювання потребують специфічних дозованих режимів призначення медикаментів. При оцінці тяжкості патологічного стану пацієнта та моніторингу відповіді на терапію використовують критерії та індекси активності захворювання $[4,5]$. Отримана інформація зазвичай вноситься до спеціалізованих баз даних та регістрів. Європейський Союз визнає актуальність регістрів, як ключових інструментів для проведення клінічних досліджень 3 вивчення рідкісних захворювань. Знеособлені дані з регістрів використовуються спеціалістами, науковцями та управлінцями для вдосконалення планування допомоги пацієнтам, покращення стандартизації терапії та порівняння результатів діяльності $[9,10]$. Персоніфіковані дані і генетична складова, обсяги медичних втручань, результати терапії, а також соціальні фактори мають величезний вплив і значення для оцінювання ризиків та прогнозу перебігу захворювання. Передусім це стосується тяжких рідкісних захворювань, що призводять до втрати здоров'я вже у дитячому віці. Оцінка тяжкості патологічного стану при рідкісному захворюванні потребує впровадження чітких критеріїв та постійного моніторингу здоров'я кожного пацієнта від моменту встановлення діагнозу та до отримання стійкого результату лікування. Саме за таких умов можливо створити відповідну систему прийняття рішення, що мінімізує існуючі ризики та дозволяє адаптувати доказові стандартні плани терапії.

Базовою основою цього процесу має стати сукупність медичних та економічних оцінок отриманих величин ризику, порівняльна характеристика 
можливих збитків для здоров’я, а також витрат на реалізацію діагностичних та терапевтичних програм. Розробка сучасних електронних експертних систем, комп'ютерного і математичного прогнозування перебігу хвороби, а також інструментів розрахунку факторів ризику може забезпечити основу для застосування інформаційних технологій моделювання у популяції дітей з ювенільним ревматоїдним артритом.

Запропоновано для задач моніторингу використовувати дві складові: персоналізований кількісний моніторинг стану дитини та інструменти підтримки прийняття рішень.

Перший процес забезпечує індивідуальну онтологію пацієнта, що містить виключно клінічну інформацію, яка $є$ актуальною для фахівців охорони здоров’я та управління цим пацієнтом. Другий - використовує сукупність критеріїв для оцінки тяжкості стану популяції пацієнтів з ювенільним ревматоїдним артритом та здійснення на їх основі математичного прогнозування ризиків захворювання.

\section{Висновки.}

1. Головним завданням в упорядкуванні та систематизації знань щодо орфанних захворювань $€$ визначення сукупності критеріїв оцінювання тяжкості та моніторингу стану, ідентифікації клінічної небезпеки та прогнозування виходів рідкісних захворювань.

2. Застосування інформаційних технологій у вивченні орфанних захворювань може вже на перших етапах застосування допомогти в визначенні факторів ризику, а також у створенні алгоритмів прийняття рішень щодо вибору тактики лікування хворих.

3. Створення системи моніторингу стану та прогнозування факторів ризику втрати здоров'я дитини потребує розробки методології створення та функціонування регістрів та розробки технологій дистанційного контролю стану хворих.

4. Клінічна модель (спостереження за дітьми з ювенільним ревматоїдним артритом), що обрана для відпрацювання логіки моніторингу стану, виявилася валідною та пертинентною.

\section{Література.}

1. Мінцер О. П. Прийняття медичних рішень в умовах ризиків виникнення інформаційної та технологічної сингулярності / О. П. Мінцер, М. В. Банчук, Н. В. Харик // Системи підтримки прийняття рішень. 2013. - Теорія і практика. — С. 100-103.

2. A community-engaged approach to quantifying caregiver preferences for the benefits and risks of emerging therapies for Duchenne muscular dystrophy / H. L. Peay, I. Hollin, R. Fischer, J. F. Bridges // Clin. Ther. 2014. - Vol. 36, No. 5. - P. 624-637.

3. Albrecht G. L. The disability paradox: high quality of life against all odds / G. L.Albrecht, P. J. Devlieger // Soc. Sci. Med. - 1999. - Vol. 48, No. 8. - P. 977-988.

4. American College of Rheumatology 2008 recommendations for the use of nonbiologic and biologic disease modifying antirheumatic drugs in rheumatoid arthritis / K. G. Saag, G. G. Teng, N. M. Patkar [et al.] // Arthritis Rheum. — 2008. — Vol. 59, No. 6. — P. 762-784.

5. Coulson E. J. What does an adult rheumatologist need to know about juvenile idiopathic arthritis? / E. J. Coulson, H. J. M. Hanson, H. E. Foster // Rheumatology. 2014. - Vol. 53, No. 12. - P. 2155-2166.

6. Harmonization of detailed clinical models with clinical study data standard / G. Jiang, J. Evans, T. A. Oniki [et al.] // Methods Inf. Med. — 2015. — Vol. 54, No. 1. — P. 65-74.

7. Henrard S. Negotiating prices of drugs for rare diseases / S. Henrard, F. Arickx // Bull. World Health Organ. 2016. - Vol. 94, No. 10. — P. 779-781.

8. Quantifying benefit-risk preferences for new medicines in rare disease patients and caregivers / T. Morèl, S. Aymé, D. Cassiman [et al.] // Orphanet J. Rare Dis. — 2016. — Vol. 11, No. 1. - P. 70.

9. Rodwell C. Rare disease policies to improve care for patients in Europe / C. Rodwell, S. Aymé // Biochim. Biophys. Acta. - 2015. — Vol. 1852, No. 10. P. 2329-2335.

10. The case for a global rare-diseases registry / C. B. Forrest, R. J. Bartek, Y. Rubinstein, S. C. Groft // The Lancet. 2011. — Vol. 377, No. 9771. — P. 1057-1059.

11. The EPIRARE proposal of a set of indicators and common data elements for the European platform for rare disease registration / D. Taruscio, E. Mollo, S. Gainotti [et al.] // Arch. Public Health. — 2014. — Vol. 72, No. 1. - P. 35. 


\section{References.}

1. Mintser, O. P., Banchuk, M. V., \& Kharik, N. V. (2013). Priinyattya medichnikh rishen' v umovakh rizikiv viniknennya informatsiinoi ta tekhnologichnoi singulyarnosti [Medical decision making in the face of the risk of information and technological singularity]. Sistemi pidtrimki priinyattya rishen'. Teoriya i praktika (Decision Support Systems. Theory and Practice), 100-103.

2. Peay, H. L., Hollin, I., Fischer, R., \& Bridges, J. F. (2014). A community-engaged approach to quantifying caregiver preferences for the benefits and risks of emerging therapies for Duchenne muscular dystrophy. Clin. Ther., 36(5), 624-637. doi: 10.1016/j. clinthera.2014.04.011.

3. Albrecht, G. L., \& Devlieger, P. J. (1999). The disability paradox: high quality of life against all odds. Soc. Sci. Med., 48(8), 977-988.

4. Saag, K. G., Teng, G. G., Patkar, N. M., Anuntiyo, J., Finney, C., Curtis, J. R., Paulus, H. E, ... Furst, D. E. (2008). American College of Rheumatology 2008 recommendations for the use of nonbiologic and biologic disease modifying antirheumatic drugs in rheumatoid arthritis. Arthritis Rheum., 59(6), 762-784. doi: 10.1002/ art.23721.
5. Coulson, E. J., Hanson. H. J. M., \& Foster, H. E. (2014). What does an adult rheumatologist need to know about juvenile idiopathic arthritis? Rheumatology, 53(12), 2155-2166. doi: 10.1093/rheumatology/keu257.

6. Jiang, G., Evans, J., Oniki, T. A., Coyle, J. F., Bain, L., Huff, S. M., Kush, R. D., \& Chute, C. G. (2015). Harmonization of detailed clinical models with clinical study data standard. Methods Inf. Med., 54(1), 65-74. doi: 10.3414/ME13-02-0019.

7. Henrard S., \& Arickx F. (2016). Negotiating prices of drugs for rare diseases. Bull. World Health Organ., 94(10), 779-781. doi: 10.2471/BLT.15.163519.

8. Morèl, T., Aymé, S., Cassiman, D., Simoens, S., Morgan, M., \& Vandebroek, M. (2016). Quantifying benefit-risk preferences for new medicines in rare disease patients and caregivers. Orphanet J. Rare Dis., 11(1), 70. doi: 10.1186/s13023-016-0444-9.

9. Rodwell, C., \& Aymé, S. (2015). Rare disease policies to improve care for patients in Europe. Biochim. Biophys. Acta., 1852(10), 2329-2335. doi: 10.1016/j. bbadis.2015.02.008.

10. Forrest, C. B., Bartek, R. J., Rubinstein, Y., \& Groft, S. C. (2011). The case for a global rare-diseases registry. The Lancet, 377(9771), 1057-1059. doi: 10.1016/S01406736(10)60680-0.

11. Taruscio, D., Mollo, E., Gainotti, S., Posada de la Paz. M., Bianchi, F., \& Vittozzi, L. (2014). The EPIRARE proposal of a set of indicators and common data elements for the European platform for rare disease registration. Arch. Public Health, 72(1), 35. doi: 10.1186/20493258-72-35. 